\title{
Performance Analysis of Key Joints and Seismic Design of High-rise Structures
}

\author{
Liu Wei ${ }^{1,2, *}$ and Shu Ganping ${ }^{2}$ \\ ${ }^{I}$ Department of Architectural Engineering, Hefei University, Hefei 230022, China; ${ }^{2}$ College of Civil Engineering, South- \\ east University, Nanjing 210096, China
}

\begin{abstract}
The structural layout and the information beyond the scope of design codes of a double-tower-connected superhigh structure were introduced. On the basis of this information, the stiffening measures of structural design were given. Furthermore, two programs are chosen to study the seismic behavior. And the results show that the main index can meet the design codes and specification. Finally, the finite element analysis of the mechanical behavior of one key joint was carried out. It can be found that the joint is elastic under some unfavorable load cases. Therefore, the joint is safe.
\end{abstract}

Keywords: High-rise structures, performance analysis, seismic design.

\section{INTRODUCTION}

The project lie in economic development zone of Taicang city in china, total height of the structure is 99.8 meter, the total building area is 70000 square meters. The structure security classification is level two, designed service life is 50 years and the foundation design grade is A class. The seismic intensity of the structures is 7 degrees, the seismic group is first group and the classification of site soil is fourth class. In accordance with standard for classification of seismic protection of building constructions [1], the project is class $\mathrm{C}$. In accordance with technical specification for concrete structures of tall building [2], the seismic grade of the structures is Class B. The architectural renderings is showed in Fig. (1).

\section{THE MAIN BUILDING STRUCTURES SYSTEM}

\subsection{Layout of Structures and Out-of-Codes Structures}

The total height of the project is 99.8 meters, including one basement and twenty six floor. The first floor height is 4.2 meter, the second floor height is 4.05 meter and other floors height is 3.85 meter. In accordance with technical specification for concrete structures of tall building [2], the project is complex high-rise building. The project is large span connecting structure and is out-of-codes structures, should be special reviewed of the earthquake.

The project has some shortcoming in between the eighth floor and twenty-second floor of large span connecting structures. The firstly, the into size $\mathrm{L} / \mathrm{B}_{\max }$ in the eighth floor to twenty-second floor of large span connecting structures is 0.32 , meeting demand of technical specification for concrete structures of tall building [2]. However, don't meet demand of code of seismic design code of buildings [3], $\mathrm{L} / \mathrm{B}_{\max }=0.3$. The secondly, Longitudinal shear wall intensively lie in the

*Address correspondence to this author at the Department of Architectural Engineering, Hefei University, Hefei, Anhui, 230022, P.R. China; Tel: +86 15055132115, E-mail: 1wdd001@163.com two housing ends in more than eighth floor, don't meeting demand of technical specification for concrete structures of tall building [2].

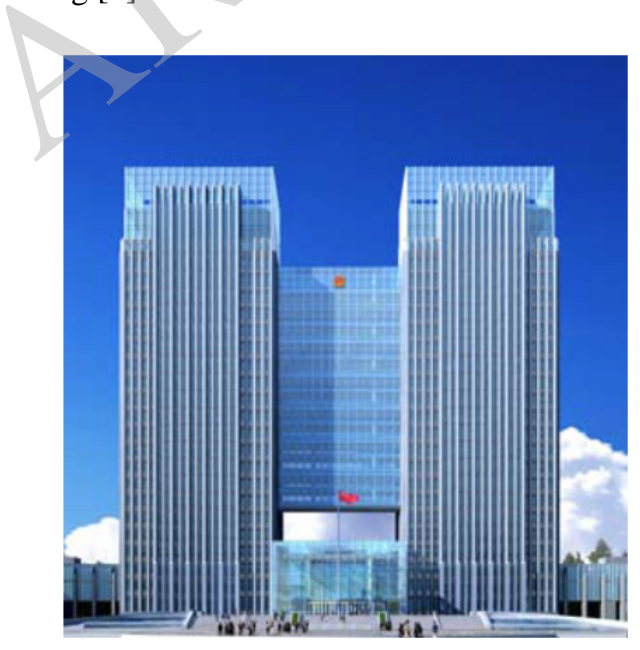

Fig. (1). Rendering views.

\subsection{Strengthening Measures of Out-Code Parts}

In the design, strengthening measures would be taken, these measures including, 1) Using calculating software PKPM SATWE made by china academy of building research to calculate the structure and analysis and using calculating software ETABS made by CKS company to recompute and analysis. Using the response spectrum method considering accidental eccentricity and coupled torsional effect under bidirectional earthquake action, the 30 modes of vibration are selected to calculated and analysis. 2) Using elastic time history analysis, the structures are supplementary analysis under frequent earthquake. The two natural waves and the one artificial wave are selected from SATWE program, the two natural waves including THITG065 and TH2TG065, the one artificial wave is RH1TG065. 3) The expected goal of the transfer truss and the frame-supporting column is that the 
transfer truss and the frame-supporting column is not in yield condition and other members maybe in destroyed condition, but these destroyed members continue to use after be repaired. The connecting part of project is elastic designed under moderate earthquake, the supporting frame column is not yield designed under moderate earthquake. 4) The transfer floor is two layer structures and is made of steel structure transformation truss. The connection part is made by steel to induce structure weight. The floor structures are made of profiled steel sheeting concrete composite slabs, the other floors is made of concrete slabs. The welding nails are welded at steel beam to ensure the reliability of the connections between steel beam and concrete slab. 5) The chord members and the roof steel beam of the connection structures extend to the end columns of the core shear wall to ensure rigid connection. The frame columns supporting transfer truss is made of steel-concrete material, the beam of the connection parts and the roof beams is made of steelconcrete material to increase bearing capability and ductility of transfer truss. 6) The large temperature variation floors of connection parts set the level of secondary beam to increase longitudinal deformation capacity of the connection parts. The height of roof slab and transfer floor is $200 \mathrm{~mm}$ to increase total structures stiffness, the other slabs height is $180 \mathrm{~mm} .7)$ Because the project is complex structures and anti-twisted capacity is worse, the strengthen bottom parts of shear wall lie in ten floors above the ground and strengthen reinforcement. The ratio of reinforcement of the horizontal and longitudinal reinforcement is 1.2 percent. The shear wall limb is restrained edge member between $1^{\text {st }}$ floor and $10^{\text {th }}$ floor.

\section{CALCULATED RESULTS AND ANALYSIS}

\subsection{Calculated Result of The Response Spectrum Method Under Frequent Earthquake}

The Table 1 show us the vibration periods of the first five vibration modes and the Table 2 show us displacement of total structures. The calculated result of Table $\mathbf{1}$ and Table $\mathbf{2}$ meet demand of codes.

\subsection{Calculation Results of Time-History Analysis Under Frequent Earthquake}

The two natural waves including THITG065 and TH2TG065 and one artificial wave RH1TG065 are selected from program SATWE, the ground maximum acceleration is $35 \mathrm{~cm} / \mathrm{s}^{2}$ when carrying on time-history analysis. The calculation results of time-history analysis are shown in Table $\mathbf{3}$ and are in agreement with results of the mode spectrum method. The calculation results meet demand of technical specification for concrete structures of tall building [2].

\subsection{Calculation Results Under Occasional Earthquake}

The structure is computed under occasional earthquake, and the results are comparatively analysis with the results under frequent earthquake and are shown in Table 4.

\section{PERFORMANCE ANALYSIS OF TRANSFER TRUSS JIONTS}

\subsection{Modeling}

The Solid45 elements are using to simulate concrete material, and the shell63 elements are using steel beam. In

Table 1. Results of the mode spectrum method-vibration periods.

(1-1)

\begin{tabular}{|c|c|c|c|c|c|c|c|c|}
\hline & $\begin{array}{l}\text { Periods } \\
\text { number }\end{array}$ & Periods (S) & $\begin{array}{l}\mathrm{X} \text { direction } \\
\text { rotation }(\%)\end{array}$ & $\begin{array}{c}\text { Y direction } \\
\text { rotation }(\%)\end{array}$ & $\begin{array}{l}\text { Twist } \\
\text { ratio }\end{array}$ & $\begin{array}{c}\text { Twist/displacement } \\
\text { Periods ratio }\end{array}$ & $\begin{array}{l}\text { Sturcture } \\
\text { mass }\end{array}$ & $\begin{array}{c}\text { Effect mass } \\
\text { coefficient } \\
(\%)\end{array}$ \\
\hline \multirow{5}{*}{ SATWE } & $\mathrm{T} 1$ & 2.6829 & 0 & 100 & 0 & \multirow{5}{*}{0.845} & \multirow{5}{*}{8879693} & \multirow{5}{*}{$\begin{array}{c}96.80 \\
\mathrm{X} \text { direction } \\
96.75 \\
\mathrm{Y} \text { direction }\end{array}$} \\
\hline & $\mathrm{T} 2$ & 2.2674 & 0 & 0 & $100 \%$ & & & \\
\hline & $\mathrm{T} 3$ & 1.6462 & 100 & 0 & 0 & & & \\
\hline & T4 & 0.6100 & 0 & 100 & 0 & & & \\
\hline & $\mathrm{T} 5$ & 0.5990 & 0 & 0 & $100 \%$ & & & \\
\hline
\end{tabular}

$(1-2)$

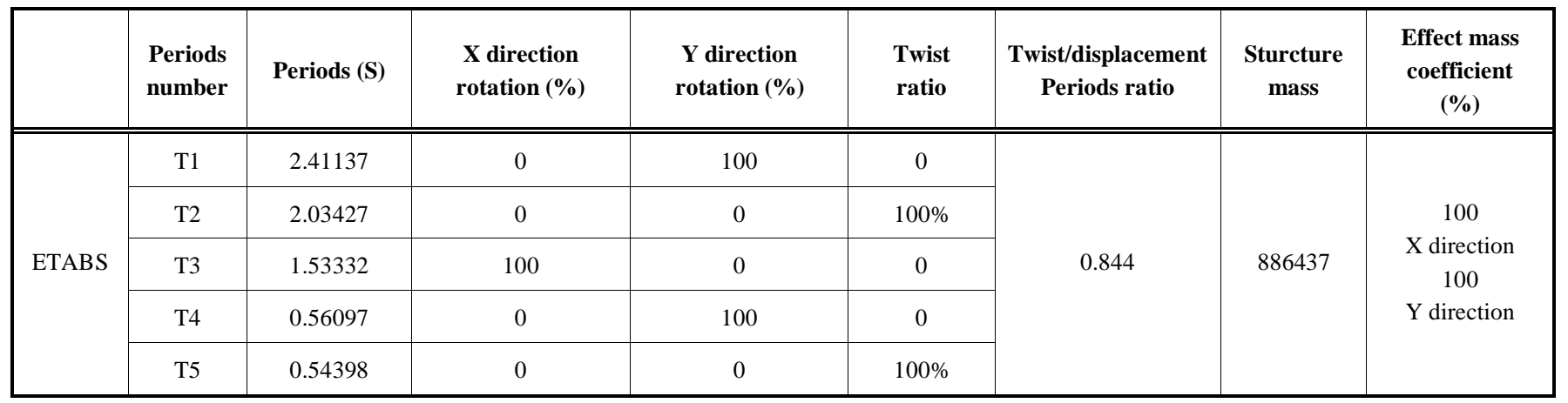


Table 2. Results of the mode spectrum method-structural displacements.

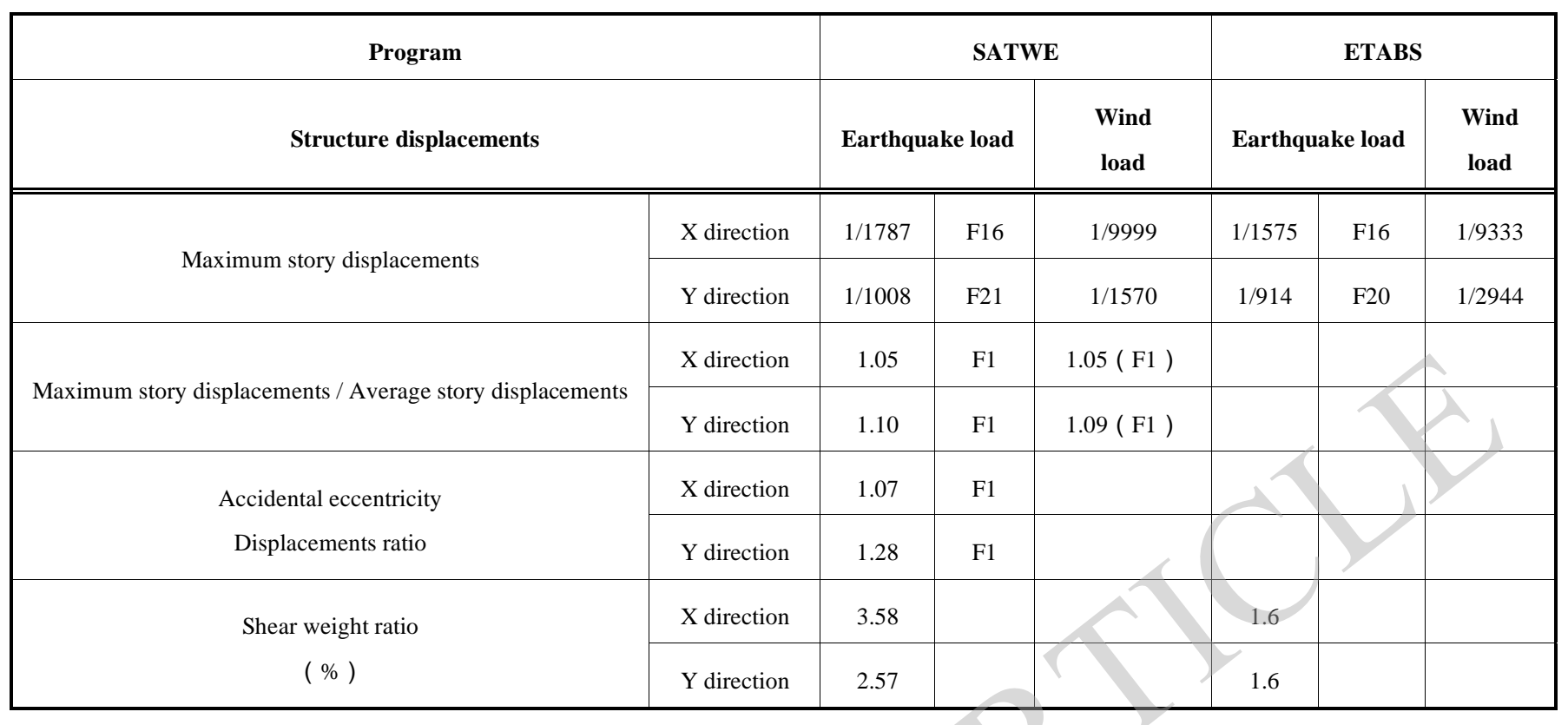

Table 3. Results of the time history.

\begin{tabular}{|c|c|c|c|c|c|c|}
\hline Time-history earthquake wave & \multicolumn{2}{|c|}{$\begin{array}{l}\text { Maximum store } \\
\text { y displacements }\end{array}$} & \multicolumn{2}{|c|}{$\begin{array}{l}\text { Maximum displacement } \\
\text { /average displacements }\end{array}$} & \multicolumn{2}{|c|}{$\begin{array}{c}\text { Shearing force /weight } \\
\text { Ratio (\%) }\end{array}$} \\
\hline TH1TG065 natural wave & $1 / 3636$ & $1 / 1820$ & 1.01 & 1.08 & 2.0 & 2.06 \\
\hline \multirow{2}{*}{ TH2TG065 natural wave } & $1 / 4121$ & $1 / 2707$ & 1.02 & 1.08 & 3.0 & 4.8 \\
\hline & F17 & F24 & $\mathrm{F} 2$ & F9 & & \\
\hline RH3TG065 artificial wave & $1 / 1920$ & $1 / 1051$ & 1.05 & 1.10 & 2.93 & 3.0 \\
\hline
\end{tabular}

Table 4. Comparison of results under the small and moderate level of earthquake.

(4-1)

\begin{tabular}{|c|c|c|}
\hline Calculation program & SATWE & SATWE \\
\hline \hline Seismic fortification intensity & 7 degree (frequent earthquake) & $0.65 \mathrm{~S}$ \\
\hline Eigen period & $0.65 \mathrm{~S}$ & $0.099 \mathrm{~g}$ \\
\hline Horizontal earthquake acceleration ratio & $0.038 \mathrm{~g}$ & 0.25 \\
\hline Horizontal earthquake influence coefficient & 0.10 & 0.035 \\
\hline Structure damping ratio & 0.035 & 0.025 \\
\hline
\end{tabular}


(Table 4) contd....

(4-2)

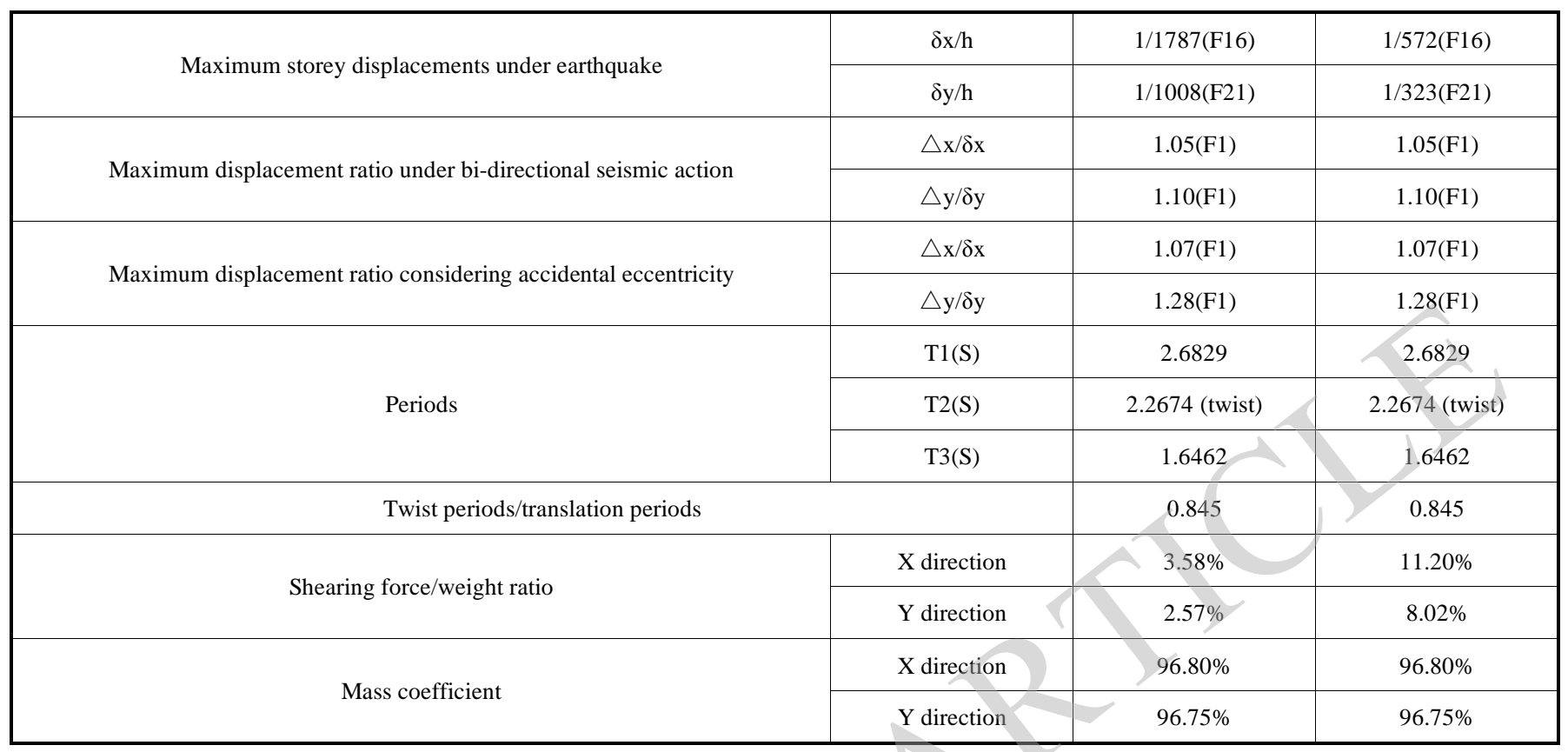

elastic analysis stage, the steel elements and the concrete elements are assumed working together, ignoring mutual slip between steel and concrete. Saint-Venant Principle think that the stress distribution near the force would change significantly and the stress distribution far the force don't change, when a small part of the surface force is change to uniform force When modeling, the length of beam and column from joint core are twice as height of beam and column to decrease error between modeling and actual project. The internal force in joint core equivalent to nodal force at end of beam and column. Fig. (2) show us about joint modeling.

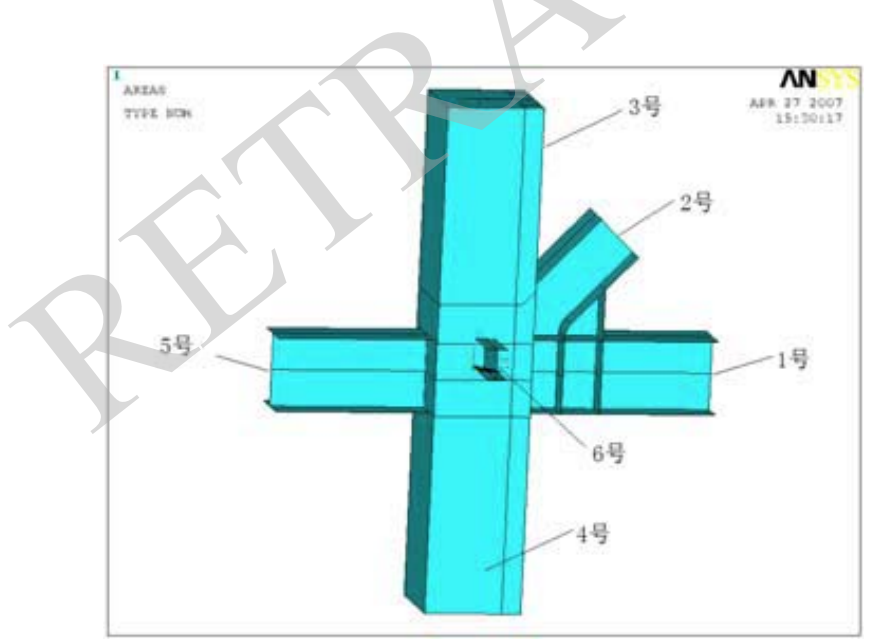

Fig. (2). Model of joints.

\subsection{Load Combinations}

The most four unfavorable combinations are selected, those is 1) Comb 28, 1.2Dead+0.6Live+0.28Wind+1.3Earthquake, 2) Comb 29, 1.2Dead+0.6Live-0.28Wind-1.3 Earth- quake, 3) Comb 36, 1.2Dead+0.5Live+0.28Wind+1.3 Earthquake, 4) Comb 37, 1.2Dead+0.5Live-0.28Wind-1.3 Earthquake. In accordance to technical specification for design of steel structure of high-rise civil buildings, the internal force of beam bearing column are multiplied by the magnification coefficient 1.5 .

\subsection{Results and Analysis}

The Fig. (3) show us equivalent Miss von stress, maximum stress is $199.1 \mathrm{Mpa}$, and maximum stress is in intersection between No1 member and No2 member. The Fig. (4) show us equivalent Miss von stress, maximum stress is $319.8 \mathrm{Mpa}$, and maximum stress is in intersection between No1 member and No2 member. The Fig. (5) show us equivalent Miss von stress, maximum stress is 202.6Mpa, and maximum stress is in intersection between No1 member and No2 member.

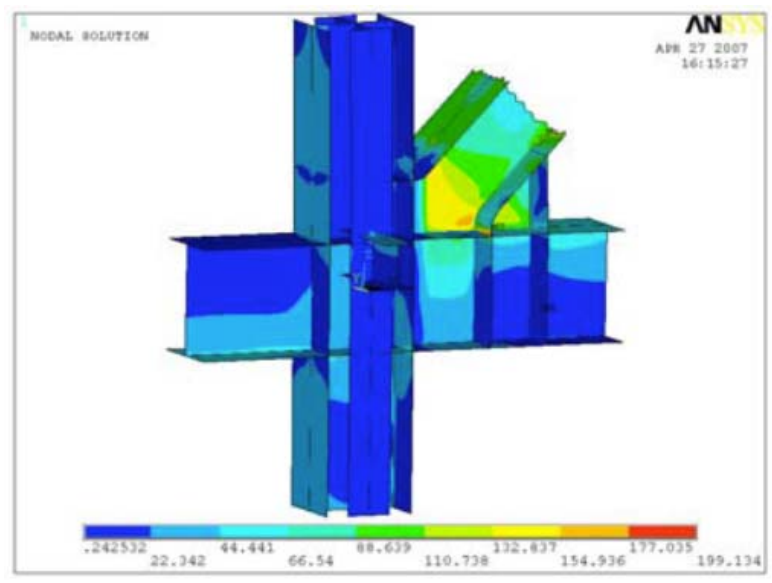

Fig. (3). Mises stress under load case 28. 


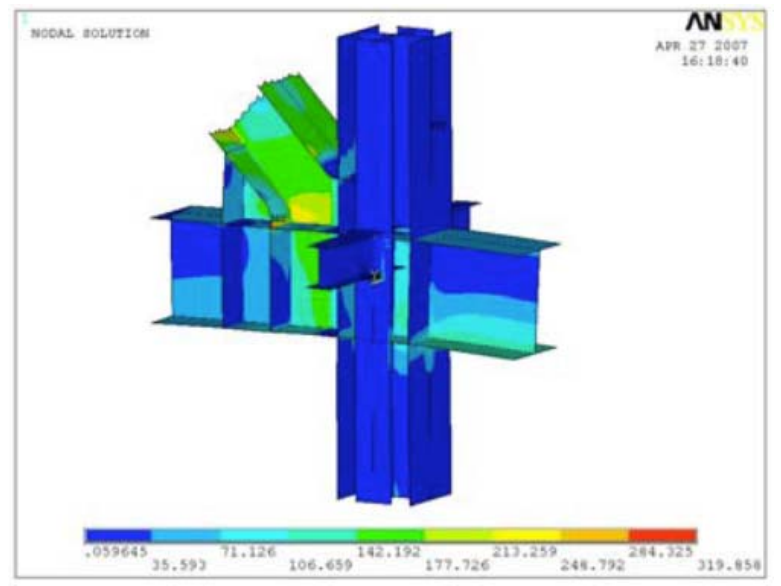

Fig. (4). Mises stress under load case 29.

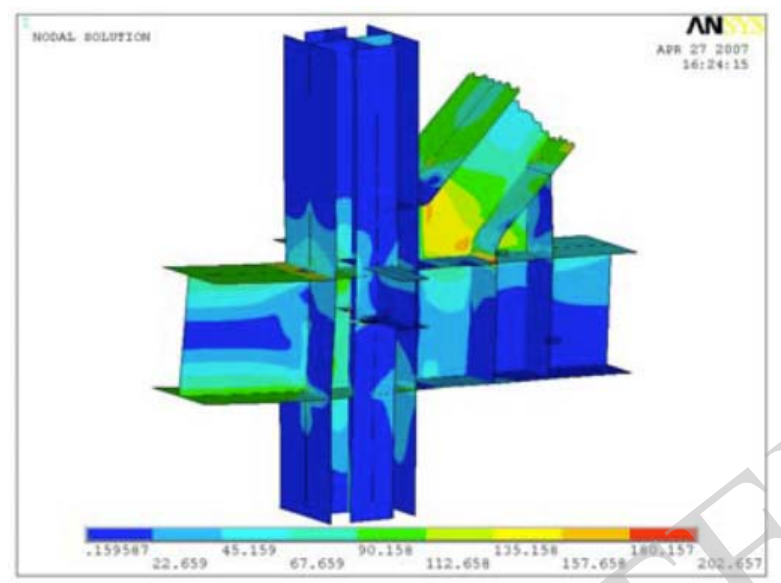

Fig. (5). Mises stress under load case 36.

\section{CONCLUSION}

The transfer truss joint are modeled by ANSYS software under four load combinations. For the second joint, the maximum load combination is comb29, the phenomenon of stress concentration appear in intersection between No1 member and No 2 member. The value of stress are 319.8 Mpa and 308.6 Mpa, so the joint is in elastic stage.

The project is out-of-codes structure with connection parts, and is modeled by SATWE program and ETABS program to calculate and analysis. The calculated results meet demand of codes and specifications. The layout of structures is used in the project and take effective measures to make up for deficiencies of structures, so the project have good seismic performance. The transfer truss joint is in elastic state and is save.

\section{CONFLICT OF INTEREST}

The authors confirm that this article content has no conflict of interest.

\section{ACKNOWLEDGEMENTS}

This work was supported by the Natural Science Foundation of the Anhui Education Institution of China (Grant No. KJ2014A217) and the Discipline Leaders of Hefei University of China (Grant No. 2014dtr01) and the the Construction of Key Subject of Hefei University of China (Grant No. 2014xk04)

\section{REFERENCES}

[1] China Academy of Building Research, Standard for Classification of Seismic Protection of Building Constructions GB 50223-2008. China Architecture \& Building Press, China, 2008, pp. 100-101.

[2] China Academy of Building Research, Technical Specification for Concrete Structures of Tall Building JBT 3-2002, China Architecture \& Building Press, China, 2002, pp. 57-58.

[3] China Academy of Building Research, Seismic Design Code of Buildings GB 50011-2001. China Architecture \& Building Press, China, 2001, pp. 34-34.

Received: January 25, 2015

Revised: March 01, 2015

Accepted: March 10, 2015

(C) Wei and Ganping; Licensee Bentham Open.

This is an open access article licensed under the terms of the Creative Commons Attribution Non-Commercial License (http://creativecommons.org/licenses/by-nc/3.0/) which permits unrestricted, non-commercial use, distribution and reproduction in any medium, provided the work is properly cited. 